\title{
Jock Young: critical criminologist
}

\author{
Alana M. Henninger
}

Published online: 11 March 2014

(C) Springer Science+Business Media Dordrecht 2014

Jock Young, one of the most distinguished and groundbreaking criminologists, died on November 16, 2013, at the age of 71. Young leaves behind a legacy of almost 50 years of innovative contributions to the study of the sociology of crime and deviance, including radical, critical, and cultural criminology; left realism; moral panics; and social bulimia. Young focused on the multitude of lenses that individuals use to view the world, and the way that certain types of people are excluded from these views (Brotherton 2013). His interests were varied, including drug users, racism, victims of crime, mass media, democratic policing, immigration, poverty among urban populations, cultures of crime, and critiques of criminal justice policy (Carlen 2012). His obituary was included in The Guardian and Times Higher Education.

Born in Midlothian Scotland on March 4, 1942, Young moved with his family at the age of five to Aldershot England. It was in Aldershot that he attended a grammar school that was heavily influenced by the town's military culture, requiring students to wear military uniforms and participate in a Cadet Force that spent hours "square bashing" (i.e., performing repeated military drills on a barrack square). Young and a group of fellow students formed an anti-Fascist/pro CND group to rebel against military activities in school, serving as Young's "opening exchange in a lifelong campaign against structural oppression and cultural imperialism" (Hayward 2010, p. 260).

Although Young intended to study biochemistry at University College London, he changed directions after meeting Marxist criminologist Steve Box (Hayward and Matthews 2013; Hayward 2010). He then entered the London School of Economics in 1962, graduating with a BSc in Sociology in 1965, a MSc in 1966, and a PhD in 1972. Young's doctoral work was greatly influenced by the counter culture revolution of the 1960s, as well as faculty interests in symbolic interactionism and

A. M. Henninger $(\bowtie)$

CUNY Graduate Center/John Jay College of Criminal Justice, New York, NY, USA

e-mail: ahenninger@jjay.cuny.edu 
labeling theory. His interest in the counter culture revolution led Young to co-found the National Deviancy Conference (NDC) in 1968, in order to provide a critical perspective on more traditional criminology. The NDC hosted bi-annual interdisciplinary conferences to provide a platform for research on the "sociology of deviance," which were heavily influenced by leftist and anarchist researchers (Hayward 2010; Hayward and Matthews 2013). Major contributors to the NDC included Stuart Hall, Paul Willis, Phil Cohen, Dick Hebdige, Mary McIntosh, and Angela McRobbie (Hayward 2010).

It was at the NDC that Young presented The Role of Police as Amplifiers of Deviancy (1968), which was the basis for his seminal work The Drugtakers (1971). The Drugtakers explored the social interactions between different groups residing in the Notting Hill neighborhood of London, which included artists, writers, drug dealers, and petty criminals of various races and ethnicities. He was very interested in the shared identity that developed out of conflicts with police officers, drug policy, and drug behavior (Hayward 2010). The concept of moral panic was also cointroduced by The Drugtakers, and his close friend Stan Cohen's Folk Devils and Moral Panics (1972). Discussions of moral panics transcended academia, becoming a popularized mainstream concept (Hayward and Matthews 2013).

In 1973, Young published The New Criminology with Ian Taylor and Paul Walton. This work critiqued criminological theories by considering the effect that structural inequalities within capitalist societies have on crime and deviance. Although the authors did not intend for The New Criminology to blaze the trail for Marxist criminologists, the global success of the book did just that. Taylor, Walton, and Young then published Critical Criminology (1975), which solidified the field of radical/critical criminology and prompted discussions on welfare capitalism, as well as the relationship between the state and the discipline of criminology (Hayward 2010).

Young joined the faculty at Middlesex University in 1986. He founded the Middlesex University Masters program in Criminology, which was targeted to criminal justice practitioners, and went on to serve as the Head of the Centre for Criminology (Carlen 2012; Hayward and Matthews 2013). It was here that Young, John Lea, and Roger Matthews began to develop Left Realist criminology in response to a local Labor Council request to establish practical responses to criminal justice problems. As the New Right rose to power in the United Kingdom, left realism provided a means to respond to the political and cultural transformations that transpired by offering a practical, policy-oriented approach to crime control. The purpose of left realism was to consider the entire social structure when responding to crime (e.g., offenders, victims, and the state), arguing that the working class is disproportionately affected by crime. He served as an advisor to the London Metropolitan Police, arguing that crime victims were most often among the impoverished and marginalized populations in society, and should be given more of a voice (Carlen 2012; Hayward and Matthews 2013). Openly critical of "get tough" policies and "nothing works" discussions, Young argued that new approaches to crime and policing needed to be developed that focused on multi-agency cooperation and a relationship between the police and the public (Hayward 2010). 
Young joined the faculty of the John Jay College of Criminal Justice of the City University of New York (CUNY) in 2002, the CUNY Graduate Center in 2004, and remained a leading faculty member until his death in 2013. He also served as a visiting professor of sociology at the University of Kent from 2005 to 2007. During his time in New York City, Young published the trilogy: The Exclusive Society (1999), The Vertigo of Late Modernity (2007), and The Criminological Imagination (2011), all of which have been widely praised as important social commentaries (Carlen 2012) on the punitive turn that criminal justice policy had taken, inclusive and exclusive societies, and social bulimia (Lilly et al. 2011; Hayward 2010).

Young has been lauded as a "leading light in radical criminology and sociology of deviance" (Garland 2012), "one of the major criminological theorists in the world" (Lilly et al. 2011, p. 220), and a "fearless intellectual" (Travis 2013). His work is internationally acclaimed and translated into eleven languages. Young was awarded the American Society of Criminology (ASC) Sellin-Glueck Prize for Outstanding International Contributions to Criminology in 1998, the ASC Critical Criminology Division Lifetime Achievement Award in 2003, the ASC Distinguished Book Award (along with Jeff Ferrell and Keith Hayward) for their coauthored book Cultural Criminology: An Invitation in 2009 and the British Society of Criminology Award for Outstanding Achievement in 2012. To those who knew him best, however, Young was "Jock the jocular, the lover of life, the supporter and mentor to hundreds if not thousands of students during his life time, the friend to us all who always had time for a drink, a laugh, and another poke at a system of absurdity and irrational design" (Brotherton 2013). He was a man who was deeply respected by all and will be greatly missed.

\section{References}

Brotherton, D. 2013. Jock's celebration speech, 12/18/13.

Carlen, P. 2012. Presenting the BSC outstanding achievement award to Jock Young. British Society of Criminology Newsletter 71: 1-6.

Garland, D. 2012. Criminology, culture, critique: A review of Jock Young, the criminological imagination. British Journal of Criminology 52(2): 417-425.

Hayward, K.J. 2010. Jock Young. In Fifty key thinkers in criminology, ed. K. Hayward, S. Maruna, and J. Mooney, 260-266. New York: Routledge.

Hayward, K., and Matthews, R. 2013. Jock Young obituary: Criminologist who questioned conventional ways of thinking about crime and its control. The Guardian. Retrieved from, http://www. theguardian.com/education/2013/dec/04/jock-young.

Lilly, J.R., F.T. Cullen, and R.A. Ball. 2011. Criminological theory: Context and Consequences, 5 th ed. Thousand Oaks: Sage Publications.

Travis, J. (2013). John Jay mourns the loss of Jock Young, Distinguished Professor of criminal justice and sociology. Retrieved from, http://www.jjay.cuny.edu/7146.php. 